\title{
Paving Paradise: The Rotal Hawaiian and The Rise of Waikiki Tourism, 1901-1929
}

By Alika Bourgette

My memory of the Royal? I recall ordering a scratch mai tai and watching a bead of condensation roll down the side of its glass. The aptly named Mai Tai Bar at the Royal Hawaiian Hotel remains one of my favorite places to enjoy a tropical cocktail. Steps removed from Waikiki Beach, the outdoor bar proves one of the best places to people-watch. Eager tourists line up at kiosks to rent surfboards, schedule catamaran tours, or buy sunscreen. Countless heads bob on the placid water protected from surging swells by a seawall. A sandcastle enthusiast duo excavates the white sand by the wheelbarrow-load to erect a 1:100 scale model of the lost city of Tenochtitlan. Even for locals, Waikiki provides an escape from the mundane.

From sacred ritual grounds to world-class resort destination to package-deal paradise, Waikiki has reinvented itself throughout its history. Unique amongst Hawaiian resort experiences, most of which offer privacy and tranquility against breath-taking beaches, Waikiki has an urban soul. Tied to the growth of Honolulu, Waikiki transitioned into a vibrant and modern cityscape in the early twentieth century. While hostelries have sat in the Waikiki sand since 1901 with the opening of the Moana, the 1920s represented the birth of Waikiki as a premier resort locale. The completions of the Ala Wai Canal in 1924 and the Royal Hawaiian Hotel in 1927 sowed the seeds for future growth of the district. This paper will chart the development of Waikiki through study of the two projects, uncovering important figures and events from broader Hawaiian history. It will also analyze popular perception and understanding of Hawaii through the early twentieth century by reviewing advertisements, newspaper and magazine articles, and literary works that revealed often patronizing and romanticized views. The Royal Hawaiian Ho- 
tel represented Hawaii's first modern, world-class resort, paving the way for Waikiki to become a successful tourist destination.

\section{Antiquity to Ala Wai: Laying the Infrastructure}

The popular, present-day image of Waikiki Beach: waving palms against a white, sandy shore looking out toward the lush, green peak of Diamond Head in the distance, would appear unrecognizable to onlookers from a century ago. Waikiki's name, which translates as "place of spouting water," harkens back to the artesian springs and flowing streams that used to feed the fertile lands. ${ }^{1}$ Prior to the 1920s and the construction of the Ala Wai Canal, the lowlands of Waikiki served as important agricultural grounds, where fishponds and taro fields provided sustenance to the inhabitants of a burgeoning Honolulu. Upon their final approach to shore, new arrivals to Honolulu Harbor passed by the quaint farming lands of Waikiki and saw a fleeting reminder of the island's past. ${ }^{2}$ By the turn of the twentieth century, the city that surrounded Waikiki developed into a modern metropolis where streetcars clanged and crowds formed and dissipated with the traffic of daily life. Waikiki, however, carried on as it always had. The broad-leafed taro rustled in the wind, surrounding the country homes where the ruling ali $i$ had once vacationed. In the days before modern tourism, Waikiki had already become recognized as a place for relaxation and enjoyment.

At Helumoa, the present-day site of the Royal Hawaiian Hotel, sat the Royal Palm Garden, a collection of over 10,000 coconut palms that found its origins in the antiquity period of Hawaiian History. The grove had religious importance to early Native Hawaiians, who had constructed heiaus (temples) on the land, and made the land accessible only to the high-ranking chiefs of Oahu. Upon his unification of the Hawaiian Islands in 1810, King Kame-

1 Masakazu Ejiri, "Development of Waikiki, 1900-1949: The Formative Period in American Resort Paradise" (PhD. diss., University of Hawaii, 1996), 20.

2 Robert L. Wiegel, "Waikiki Beach, Oahu, Hawaii: History of Its Transformation From a Natural to an Urban Shore,"Shore and Beach 76 (Spring 2008), 3. 
hameha I selected Helumoa as his administrative center on the island. ${ }^{3}$ After Kamehameha I's reign, Helumoa fell out of religious use, but remained a royal residence for his descendants. Access to fresh water and a secluded beach, along with the shade and privacy afforded by the Royal Palm Garden made Helumoa a favorite retreat for Hawaii's rulers, who had relocated official residence into Honolulu proper. ${ }^{4}$ King Kamehameha V (1863-1872) developed the parcel that would become the Royal Hawaiian Hotel for his personal use. The land today remains held in trust by the estate of Princess Bernice Pauahi Bishop, one of the largest and wealthiest land-holding trusts in Hawaii ${ }^{5}$.

Before Waikiki could begin its transformation from underdeveloped, private retreat for royalty to premium resort locale for the merely wealthy, the land had to be reshaped to this purpose. The 'spouting waters' of Waikiki rendered its soils saturated and prone to flooding. The streams that fed the Waikiki with fresh water also carried silt and alluvium from the nearby mountains into the wetlands and out to the sea. The first decades of the twentieth century brought increased development to the area, which interrupted the natural processes of erosion and water flow. The construction of Kalakaua Avenue and the first Waikiki resorts, including the Moana and the Seaside between 1901 and 1906, resulted in the disruption of natural drainage of freshwater to the ocean. ${ }^{6}$ As a result, the streams that fed Waikiki became stagnant and filled with silt. The muck that filled the wetlands surrounding the first Waikiki resorts fomented unsanitary conditions. In 1913, the seepage of fetid water reached the shores of the Moana Hotel, sparking tourists' disgust and protest. According to an account in the Pacific Commercial Advertiser, one resort patron demanded, "something be done to prevent a future display of river sweepings in what has been advertised as one of the most romantic and perfect tempered

3 Andrea Feeser and Gaye Chan, Waikiki: A History of Forgetting and Remembering (University of Hawaii Press, 2007), 65.

4 Ejiri, 75.

5 Feeser and Chan, 66.

6 Wiegel, 6. 
bathing places in the world." That something came in the form of the dredging of the Ala Wai Canal in 1921.

The construction of the Ala Wai Canal allowed for the reclamation of Waikiki, paving the way for the area to become a successful resort destination. Two men helped shape the creation of the canal, Lucius Eugene Pinkham, Governor of the Territory of Hawaii from 1913-1918, and Walter Francis Dillingham, owner of the Hawaiian Dredging Company. On February 21, 1906, Pinkham, President of the Board of Health, announced his plan, stating that the wetlands were "incapable of drainage" and "in an unsanitary and dangerous condition." ${ }^{8}$ However, from plan's onset, Waikiki residents understood the true nature of the dredging project. The creation of the canal would dry the taro farms and fishponds along the coast and imperil their livelihood. Furthermore, Pinkham's plan included the introduction of a grid pattern to Waikiki that could incorporate building sites for real property. Of the redevelopment, Pinkham stated, "In making my plan, I merely suggested to [the City Surveyor] that we put in streets, connecting up the roads, and this was done, but without the idea that the plan as drawn was an arbitrary one. I believe the land could be sold, perhaps to newcomers. Anyway, it is going to be a go." ${ }^{9}$ With that, Pinkham revealed his true intention for Waikiki to shed its provincial status as a reminder of Oahu's agrarian past. The inception of the Ala Wai Canal allowed for the incorporation of Waikiki into the modern city of Honolulu as its premier resort district.

Once planned, initiating the groundwork for the Ala Wai Canal proved challenging. Appointed Territory Governor of Hawaii by President Woodrow Wilson in 1913, Pinkham finally gained the political authority necessary to enact his plan. Having worked longtime for the Oahu Railway and Land Company and Pacific Hardware, both Dillingham-owned firms, it followed

\footnotetext{
7 "Sluiced Lagoon Water into Waikiki Water and Drove Fair Bathers Away," The Pacific Commercial Advertiser. February 16, 1913, 9, Chronicling America: Historic American Newspapers. Lib. of Congress.

8 "Pinkham Plans the Reclamation of All Waikiki," Evening Bulletin. February 21, 1906, 1, Chronicling America: Historic American Newspapers. Lib. of Congress.

9 "Pinkham Plan to Reclaim Waikiki to be Tried," The Pacific Commercial Advertiser. March 16, 1906, 5 , Chronicling America: Historic American Newspapers. Lib. of Congress.
} 
that Pinkham awarded the Ala Wai Canal contract to his friend Walter Francis Dillingham's Hawaiian Dredging Company. ${ }^{10}$ The canal would run a twomile stretch roughly parallel with the coast, capturing the drainage of Waikiki's streams, carrying the water to the ocean at Ala Wai Harbor. Pinkham secured the land necessary to begin dredging through eminent domain. When dredging began in 1921, the families displaced by the project refused to vacate their land, with some remaining until dredging crews arrived at their door. ${ }^{11}$ The soils dredged from the canal served as filling material for the wetlands on either side. In this way, Dillingham's Hawaiian Dredging Company converted 687 acres of wet agricultural land into a space suitable for real estate. ${ }^{12}$

Dillingham enacted Pinkham's vision of creating a canal that would form a focal point for tourism in Hawaii. While the reclamation of Waikiki did allow for future development of the land, the Ala Wai Canal failed to live up to expectations of because of shortcomings in its design. Pinkham envisioned the canal itself as an attraction, regarding it as the "Venice of the Pacific." However, upon the project's completion in 1924, Dillingham had led it over its $\$ 100,000$ budget. To reduce costs, he scraped a planned second outlet to the ocean that would have ran through Kapiolani Park on the canal's end nearer to Diamond Head. ${ }^{13}$ With its only outlet at the Ala Wai Harbor, the canal became a basin for sediment and run-off that used to flow out to sea along the natural streams of Waikiki. Accumulating 8,000 to 10,000 cubic yards of siltation a year and requiring periodic re-dredging, the Ala Wai Canal today remains a source of pollutants dangerous to human health and damaging to the environment surrounding Waikiki. ${ }^{14}$ Instead of solving the health risk posed by the stagnant waters that collected in Waikiki, Pinkham's canal moved the issue further inland and contained it within the banks of the Ala Wai. Nonetheless, with Waikiki cleared of farmland and open to real estate

\footnotetext{
10 Ejiri, 242.

11 Feeser and Chan, 27.

12 Ejiri, 239.

13 Ejiri, 250-251.

14 Wiegel, 12.
} 
development, the Ala Wai Canal irreversibly changed Waikiki's place within the cityscape. Pinkham's dream of a resort paradise within Honolulu would soon become reality.

\section{Conceptions of Hawaii: Ads, Articles, and Literature}

Mainlanders' conception of Hawaii at the turn of the twentieth century shaped the way Waikiki tourism developed. Early literary accounts of Hawaii, steeped in patronizing and romanticized imagery, captured the imaginations of tourist advertisers, travel writers, and ultimately the broader public-at-large. In the decades bookending the year 1900, notable American literary figures, including Mark Twain, Robert Louis Stevenson, and Jack London, harbored a fascination for Hawaii and produce titles describing their experiences with positive enthusiasm. As the most contemporaneous of the three, Jack London's tales crystallized the stereotypical image of Hawaii in the minds of the article writers and advertisers in the first half of the twentieth century. Jack London visited Hawaii twice. First in 1907 aboard his voyaging yacht, the Snark, as part of a broader tour of the South Pacific, and then again in late 1915, making at that time a more extended stay. ${ }^{15}$ During his initial visit, he rented a tent cabin on the premises of the Seaside Hotel in Waikiki. He spent time their gathering inspiration for his collection of South Seas stories, and needed to look no further than beyond his front door, where he observed a group of locals surfing, which he called, "a royal sport for the natural kings of earth." ${ }^{16}$ London at first contented himself to observe the surfers at play, awed by their mastery of the sport. Catching their attention, the group offered to teach him how to surf, and he accepted. Though he did not succeed in catching a wave, the experience resonated with him. In his story "A Royal Sport," he remarked:

Where but the moment before was only wide desolation and invincible roar, is now a man erect, full-stature, not struggling frantically in that wild movement, not buried and crush and buffeted by those mighty monsters, but

15 James L. Haley, Wolf: The Lives of Jack London (New York: Basic Books, 2010), 247, 300.

16 Jack London, "A Royal Sport" in The Cruise of the Snark: Jack London's South Sea Adventure (Santa Barbara: Narrative Press, 2001), 50. 
standing above them all....flying forward, flying fast as teh surge on which he stands. he is a Mercury - a brown Mercury. ${ }^{17}$

Jack London's depiction of Native Hawaiians as friendly and civilized, yet primitive became an established caricature for nonwhite peoples of Hawaii. London's observations, similar to other accounts from the time, revealed a romanticized notion of Orientalism popular in the late Victorian period into the early twentieth century. ${ }^{18}$ As Hawaii started to grow into a tourist destination, idealized perceptions of the islands dominated advertisements and travel articles of the period.

Early tourist literature crafted a romanticized vision of Hawaii, promoting its exoticism through idealized observations. Following Jack London's lead, travel writers sought out "authentic" experiences of their own when visiting Hawaii; however, the experiences they shared revealed their paternal fascination with "native" culture. Viewing a society they saw as vastly different from their own, visiting writers believed that the experiences they captured harkened back to a primitive past. ${ }^{19}$ Hawaiian water sports, in particular, found popularity in tourist narratives. Of outrigger canoeing, a Los Angeles Times journalist wrote:

There is a native in the prow to paddle and another in the stern to steer and when they get the canoe about half way over to San Francisco, suddenly they decide to turn around and let the sportive billows play tag with helpless you. From long years of experience these natives know just when and where to make this turn, and best of all, they know how to do it. ${ }^{20}$

As also seen in Jack London's accounts of surfing, water sports provided an opportunity for visitors to imagine an idyllic island culture removed from modern complications. The unique cultural experiences they encountered allowed tourists to romanticize Hawaii as a timeless land immune to the ravages of modernity. A travel writer for Vogue captured this sentiment, stating of

17 “Truth About Waikiki Beach," Los Angeles Times, June 6, 1920, III, 32, ProQuest Historical Newspapers.

18 Edward W. Said, Orientalism (New York: Vintage Books, 1979).

19 Jane Desmond, "Picturing Hawaii: The "Ideal" Native and the Origins of Tourism, 1880-1915," in Positions: East Asia Culture Critique 7 (Duke University Press, 1999), 462.

20 “Truth About Waikiki Beach," Los Angeles Times, June 6, 1920, III, 32, ProQuest Historical Newspapers. 
Honolulu, "It is the most Oriental of Occidental cities, the most Occidental of Oriental; and, since it is so distant from the customary center of human habitation, the eyes of weary men turn towards it wistfully as a haven of escape from the habitual." ${ }^{21}$ The writer's remarks showcased the belief that Hawaii, with its Eastern exoticism, provided the antidote to the pressures of modern, urban Western society. In Hawaii, tourist writers found an Edenic paradise peopled with a genteel, multiethnic population that lived in relative harmony. In idealized Hawaii, "natives" engaged themselves in traditional sport, and lived as they had for centuries. Partaking in experiences such as surfing and outrigger paddling promoted a positive connection with the locals the tourists encountered. ${ }^{22}$ Tourist advertisements captured and distilled such experiences, further shaping Hawaii's growth as a vacation destination.

Beginning in earnest in the early 1920s, tourist advertisements helped introduce Hawaii to mainland audiences. As sea travel at the turn of twentieth century had proven prohibitive to most, save for the very rich, 1920s consumers turned to pictures and written accounts for their knowledge of Hawaii. Advertisements, therefore, often provided potential tourists with most, if not all, of their information of the islands. ${ }^{23}$ Focusing their attention on its moderate climate and outdoor features, early advertisements sold Hawaii as having "Spring eleven months of the year," and "great hiking." ${ }^{24}$ As the decade progressed, advertisements began to adopt a more personal tone, appealing more directly to the reader's sensibilities. ${ }^{25}$ Advertising Hawaii tourism, too, followed this trend, with one ad beginning:

Who hasn't dreamed since childhood of riding the surf in outrigger canoes at Waikiki; of standing on the brink of the crater of Kilauea, the greatest active volcano in the world; of the cocoanut [sic.] fringed shores and brilliant

21 Clayton Hamilton, "Honolulu Holds the Magic Mirror for Mankind," Vogue, January 1, 1924, 56.

22 Desmond, 464.

23 Desmond, 465.

24 Collected from advertisements in Los Angeles Times from August 5, 1923 and November 12, 1925.

25 Roland Marchand, "Apostles of Modernity" in Advertising the American Dream (University of California Press, 1985), 9. 
tropical flowing trees. Don't dream about Hawaii any longer, come now. ${ }^{26}$

This ad from the Bank of Hawaii soliciting mail and banking services for travelers reached out to the reader in an interactive way, allowing him to envision the activities he might do on a Hawaiian vacation. New advertising schemes helped familiarize consumers with Hawaii by providing specific details and establishing an emotional connection. 1920s advertisers also compared Hawaii to more familiar destination as a strategy used to impart a favorable image. A two-page ad by the Los Angeles Steamship Company entitled, "Enchanted Islands," discussed the accommodations of the newly opened Royal Hawaiian and surrounding amenities alongside available excursions to Catalina Island, a well-trodden destination for Southern Californians. Written in the style of an informational article, the piece contrasted the newness and quality of the Royal Hawaiian and related Waialae Country Club with the amenities available on Catalina Island "that continue to be crowded." ${ }^{27}$ Improved advertisement strategies promoted awareness of Hawaii as a resort destination and helped build Waikiki as a brand. The modernization of attempts at advertising Hawaii mirrored the developments Waikiki made itself as it progressed into a playground for the elite.

\section{The Royal Hawaiian, Matson Navigation, and Sailing into Modernity}

From the moment new arrivals disembarked from their motorcars and mounted the steps of the Royal Hawaiian Hotel, they found themselves transported to a world of luxury. Pink pillars lined long lanais furnished with sturdy maple chairs looking out upon a green courtyard shaded by waving palms. The open-air interior provided guests with further space to gather or stroll through the premises past drawing lobbies, tearooms, and outdoor dining rooms. ${ }^{28}$ Upon its opening on February 1, 1927, the Royal offered guests a hostelry experience never before offered in Waikiki. The Royal Hawaiian

\footnotetext{
26 Advertisement: The Bank of Hawaii. Los Angeles Times, January 1, 1925. E29.

27 Advertisement: "Enchanted Islands," Los Angeles Times, January 3, 1928. F12.

28 Agnes Mavo James, "Exotic Honolulu," Vogue, January 1, 1928, 56, 114.
} 
set the bar for future development. Waikiki had its first world-class resort.

Central to the Royal Hawaiian's inception sat Edward Tenney, president of Castle \& Cooke and Matson Navigation, two of Hawaii's largest corporations. ${ }^{29}$ Both companies had come to prominence in Hawaii's business and political spheres over the course of the nineteenth century during late monarchy and republican periods. Tenney's companies, alongside the other corporations that comprised Hawaii's "Big Five," had come to control 96 percent of the sugar industry, most of the pineapple industry, and virtually all of the islands' shipping by the 1930 s. $^{30}$ Family members of the Big Five had controlled the governments both of Honolulu and the Hawaiian Islands as a whole since the signing of the 1887 "Bayonet" Constitution by King David Kalākaua. ${ }^{31}$ In 1925, Matson Navigation, already involved freight and passenger liners, endeavored to enter the luxury steamship market with the construction of the S.S. Malolo (flying fish). A luxury route to Hawaii would open Waikiki to a new market of tourist, a well-travelled and worldly class with the highest expectations in amenities. The Moana and the Seaside, Waikiki's two largest resorts, suffered in the past from customer complaints. Tenney, after approving the Malolo, understood that in order to attract the most affluent passengers to visit Hawaii, a new hotel would have to be built to satisfy future demands. ${ }^{32}$ Exercising his considerable influence, Tenney orchestrated the purchase of Territorial Hotel Company Ltd. under Matson Navigation. Castle \& Cooke underwrote the transaction, bringing all three entities under Tenney's control. ${ }^{33}$ With his corporate interests aligned, Tenney set forth the projects that would become the S.S. Malolo and the Royal Hawaiian.

Designed to accommodate world-class travelers, the S.S. Malolo and the

29 Don J. Hibbard, Designing Paradise: The Allure of the Hawaiian Resort (Princeton: Princeton Architectural Press, 2006), 43.

30 John S. Whitehead, "Western Progressives, Old South Planters, or Colonial Oppressors: The Enigma of Hawaii's “Big Five" 1898-1940." in Western Historical Quarterly 30 (Oxford University Press, 1999). 296.

31 "New Hawaiian Constitution Adopted July 7, 1887," The Daily Bulletin, July 7, 1887, Chronicling America: Historic American Newspapers. Lib. of Congress; Whitehead, 298.

32 Ejiri, 253.

33 Stan Cohen, The Pink Palace (Missoula: Pictorial Histories Publishing, 1986), 17-18. 
Royal Hawaiian Hotel expressed trends in high culture and the interests of the affluent in the 1920s. Finished ahead of the Royal Hawaiian's opening, the Malolo incorporated the all the modern conveniences expected of a luxury passenger liner. According to a Matson advertisement, the ship featured, "accommodations for 600 first class passengers, seven decks for passengers' use, elevators serve all decks, motion picture theatre, ballroom, completely equipped gymnasium, children's playroom and huge Pompeian swimming pool." ${ }^{44}$ Providing all of the traditional amenities while including popular trends in entertainment, such as motion pictures, the Malolo's design embraced modernity without sacrificing elegance. Advertised that the "swiftest passenger vessel ever built in the United States," the Malolo made the transit between San Francisco and Honolulu in four days, a day faster than comparable ships. ${ }^{35}$ The swift, elegant Malolo met passengers' desires in providing a quality seafaring experience. The design of the Royal Hawaiian Hotel followed the same standard.

Designed by New York architecture firm, Warren \& Wetmore, the Royal Hawaiian shared a pedigree with some of the East Coast's finest buildings, including the Ritz-Carlton, Biltmore, and Ambassador Hotels in New York, and Grand Central Terminal. ${ }^{36}$ The architects chose to build the Royal in the Spanish Colonial Revival style, finding the motif complementary to Hawaii's moderate climate, and also following the renewed interest in the colonial style in the 1920s. The Spanish Colonial style reemerged in the American West at the turn of the century as tourists began to look at the edificial vestiges of the Spanish period through a romantic lens. In the same era that Californians began to restore the broken arches of their Spanish missions, the Royal Hawaiian gained a 150 -foot mission-style bell tower. ${ }^{37}$ The building followed an 'H' pattern to capture Hawaii's famed trade winds. One of the two long

34 Advertisement: "Matson Line," Forum (1886-1930). April 1, 1928. 69. ProQuest American Periodicals.

35 Advertisement: "Christmas in Honolulu," Los Angeles Times, December 17, 1927, 6.

36 Hibbard, 41.

37 Phoebe S. Kropp, "The Road: El Camino Real and Mission Nostalgia" in California Vieja: Culture and Memory in a Modern American Place (University of California Press, 2006), 75; Hibbard, 41. 
wings faced the beach, affording views of the beach and Diamond Head. The rest of the hotel enjoyed seclusion, being surrounded by lush tropical garden scenery. Of the Royal's well-landscaped grounds, a Vogue feature article remarked, "a world-traveled group recently indicated the Royal Hawaiian as the smartest and most luxurious hotel visited on their entire voyage." ${ }^{38}$ While the grounds themselves gave the resort a grandiose air, the finer details, the activities and amenities that the Royal purveyed, established its preeminence amongst Waikiki hostelries.

The Royal Hawaiian provided its guests with superior amenities that satisfied the interests of modern travelers. Promoters for the Royal Hawaiian lauded most the associated Waialae Golf Club, built for the exclusive use of hotel patrons. "Designed to test the golfer's ability with the greatest possible variety of shots," ${ }^{9}$ Waialae Golf Club was built by renowned course designer, Seth Raynor, who reproduced at Waialae several holes from internationally famed course, including Saint Andrews and North Berwick in Scotland, and Biarritz in France. ${ }^{40}$ Off of the links, the Royal Hawaiian offered opportunities for game fishing along the windward coast, polo and trail riding at the Diamond Head stables, motor touring up Tantalus and the Nu'uanu Pali, and, of course, surfing and outrigger canoe paddling on Waikiki Beach. ${ }^{41}$ In short, the Royal Hawaiian Hotel appealed to the modern tastes of their affluent clientele. Controlling the means by which their guests arrived to the islands, the Royal Hawaiian provided the services necessary to ensure travelers enjoyed their stay to the fullest. Passengers aboard the Malolo could arrive at the dock in Los Angeles and San Francisco in their automobiles and make the four-day crossing to Honolulu with their vehicles in comfort and ease. Once ashore, the Royal Hawaiian provided capacious, well-appointed confines and offered activities that made boredom impossible. One needs not wonder why visitors to Waikiki often planned to stay for three weeks or more. The Royal represented

38 James, 114.

39 James, 114.

40 Hibbard, 43.

41 Advertisement: Royal Hawaiian Hotel, Vogue, October 1, 1927, 40; James, 115. 
a veritable paradise for the affluent elite. The rise world-class resort options and luxury steam line service to Waikiki made the destination popular with luminaries of the entertainment industry.

The amenities at the Royal Hawaiian proved irresistible for Hollywood's stars. Such notables as Charlie Chaplin, Shirley Temple, Clarke Gable, Groucho Marx, Bing Crosby, Mary Pickford and Douglas Fairbanks made the Royal a destination for respite between film productions. ${ }^{42}$ Mary Pickford and Douglas Fairbanks, then King and Queen of the motion picture screen, made frequent visits to the Royal between the festivities of the hotel's opening night, of which they partook, and the collapse of their marriage in $1928 .{ }^{43}$ Another onscreen romantic duo of the silent era, Norma Talmadge and Gilbert Roland made headlines in the Los Angeles Times when they held up the production of their 1929 release New York Nights in order to take a spontaneous vacation to Waikiki, choosing to stay at the Royal Hawaiian. Of the decision, Talmadge stated, "Neither of us has seen Hawaii and hearing such a lot about its romantic charm we both wanted to go. You see, we can keep in touch with the story of the picture way, since we intend to resume work immediately upon our return." ${ }^{44}$ For movie stars, the hop to Hawaii came with relative ease. Before an isolated outpost apart from the center of civilization, Waikiki transitioned into a haunt for America's socialites. As Waikiki became more familiar to rich celebrities, the district's nightlife grew to match their tastes.

As notable figures from the entertainment industry flocked to Waikiki, they brought with them the nightlife trends of the Jazz Age. Floating on swung rhythms and a pulsing backbeat, Jazz music fueled a cultural phenomenon throughout America in the "roaring twenties." Played everywhere from concert halls to dance halls to living room "petting parties," Jazz became the standard and expectation when it came to nighttime entertainment. 1920s Waikiki provided no exception. Don Blanding, described as "Hawaii's Poet

\footnotetext{
42 Hibbard, 45.

43 Cohen, 44.

44 "Film Players off to Hawaii: Picture Held Up for Their Vacation," Los Angeles Times, June 3, 1928, C1, ProQuest Historical Newspapers.
} 
Laureate" during his time, captured an image of Waikiki nightlife in his prose poem, "Waikiki," stating:

The area surrounding the two big hotels, the Moana and the Royal Hawaiian, is known as Flappers' Acre... The jazz bands from the two beach hotels fing dance tunes over Flappers' Acre. Automobiles swish in and out of the narrow streets, filled with pretty girls and their escorts. ${ }^{45}$

Referencing the iconic women's subculture movement of the Jazz Age, Blanding's accounts identified a specific district, centered on the Royal Hawaiian, as the epicenter of Jazz nightlife in Waikiki. In fact, local musician Johnny Noble, originally the conductor of the Moana Hotel Orchestra, led Jazz ensembles at both hotels throughout the decade. ${ }^{46}$ After taking in a night of Jazz at the Royal Hawaiian, a travel writer noted, "a Hawaiian orchestra play[ed] the latest "jazz," interspersed with an occasional native air." ${ }^{47}$ By the time the Royal Hawaiian had first opened its doors, local bandleaders had not only incorporated elements of Jazz into their repertoire, they had made it their own. Accounts of Waikiki's nightlife attested to its vibrancy. On a nighttime stroll down Kalakaua Avenue along Blanding's "Flappers' Acre," an observer might have encountered young couples in automobiles listening to the faint din of Hawaiian Jazz compositions, such as Johnny Noble's "Hula Blues," escaping from hotel fronts. In the course of a decade, Waikiki had transformed from a provincial holdover from a bygone time to a modern, urban retreat for society's upper crust. In the form of Jazz music, Waikiki had even adopted the sounds of modernity.

\section{Conclusion}

Perhaps prophetically, Jack London wrote in a correspondence during his 19151916 visit to Waikiki: "I'm glad we're here now...For someday Waikiki Beach is going to be the scene of one long Hotel." ${ }^{48}$ Waikiki today, with its high-rise

45 Don Blanding, "Waikiki," in Hula Moons (New York: Dodd, Mead \& Company, 1930), 209.

46 Ejiri, 197.

47 Rosemary Bevan Karelle, "Honolulu: This Hawaiian Paradise Bewitches the Visitor with Its Sea, Its Hills, and Its Magical Moon in a Tropical Night,” Vogue, October 15, 1927, 136.

48 Ejiri, 136. 
hotels and apartments, constant traffic, and crowded beach, owes much to the 1920s developments of the Ala Wai Canal and Royal Hawaiian Hotel. The canal, while flawed, diverted stream waters away from taro farms, fishponds, and noble Hemuloa, the former country residence of royalty. Once dried, Waikiki gained its current grid pattern as part of Pinkham's dream of creating an urban resort paradise. Literary notables, such as Jack London, helped conceive the image of Hawaii that advertisers and article writers would emulate throughout the 1920s. London's Waikiki of gentle native busy in their preoccupations of surf and sea formed an iconic image of idyllic Waikiki reprised in fashion magazines and newspapers. Advertising efforts by Hawaiian businesses primed affluent consumers' interests in a Hawaiian luxury resort experience. Edward Tenney, through his vast corporate empire, set the plans in motion for a combined vacation and travel experience aboard the S.S. Malolo with lodgings at the Royal Hawaiian Hotel. The Royal's accommodations attracted the wealthiest patrons, including the Hollywood elite. High-powered names made the Royal their quick getaway stop away from the grueling demands of film production. At night the Royal Hawaiian transformed into Don Blanding's "Flappers' Acre," where Jazz music, hybridized with the sounds of Hawaii, filled the orchid-scented air. Further shore improvements between the 1930s to present would give Waikiki Beach its current configuration. Combating beach erosion remains a constant effort for Honolulu's engineers. Man-made seawalls protect the shore from the full force of Waikiki's surf. As recently as 2012, 27,000 cubic feet of sand had to be pumped in from off shore to restore the beachfront. According to the $\mathrm{Ha}-$ waii Tourism Authority, a record 8.3 million visitors came to Hawaii in 2014, collectively spending $\$ 14.7$ billion dollars whilst there. ${ }^{49}$ Waikiki serves today as the gateway to that industry as the most popular Hawaiian destination for first-time visitors. The Royal Hawaiian remains today a popular luxury resort. In 2008 , the hotel underwent a seven-month, $\$ 110$ million renovation to better provide guests an experience worthy of its name. ${ }^{50}$ Though artificial in every sense, Waikiki remains an icon of Hawaii tourism.

49 “December 2014 Visitors Stat Press Release," Hawaii Tourism Authority, January 29, 2015.

50 Gene Park, "Royal Hawaiian Closing for 7 Months," Honolulu Start Bulletin, June 1, 2008. 
Blanding, Don, "Waikiki," in Hula Moons. New York: Dodd, Mead \& Company, 1930.

"Christmas in Honolulu," Advertisement. Los Angeles Times. December 17, 1927.

Cocke, Sophie, "Waikiki Beach is Totally Man-Made (and Disappearing). Can Hawaii Save It?” Huffington Post. March 9, 2015. http://www.huffingtonpost. com/2015/03/09/saving-waikiki-beach-erosion_n_6835424.html.

Cohen, Stan. The Pink Palace. Missoula: Pictorial Histories Publishing, 1986.

"December 2014 Visitors Stat Press Release," Hawaii Tourism Authority. January 29, 2015.

Desmond, Jane. "Picturing Hawaii: The "Ideal" Native and the Origins of Tourism, 1880-1915.” Positions: East Asia Culture Critique 7. Duke University Press, 1999.

Ejiri, Masakazu. "Development of Waikiki, 1900-1949: The Formative Period in American Resort Paradise.” PhD. dissertation, University of Hawaii, 1996.

“Enchanted Islands.” Advertisement. Los Angeles Times. January 3, 1928.

Feeser, Andrea and Chan, Gaye. Waikiki: A History of Forgetting and Remembering. University of Hawaii Press, 2007.

"Film Players off to Hawaii: Picture Held Up for Their Vacation." Los Angeles Times. June 3, 1928. ProQuest Historical Newspapers.

Haley, James L. Wolf: The Lives of Jack London. New York: Basic Books, 2010.

Hamilton, Clayton. "Honolulu Holds the Magic Mirror for Mankind.” Vogue. January $1,1924$.

Hibbard, Don J. Designing Paradise: The Allure of the Hawaiian Resort. Princeton:

Princeton Architectural Press, 2006.

James, Agnes Mayo. “Exotic Honolulu.” Vogue. January 1, 1928.

Karelle, Rosemary Bevan. "Honolulu: This Hawaiian Paradise Bewitches the Visitor 
with Its Sea, Its Hills, and Its Magical Moon in a Tropical Night.” Vogue. October 15, 1927.

Kropp, Phoebe S. "The Road: El Camino Real and Mission Nostalgia." California Vieja: Culture and Memory in a Modern American Place. Berkeley: University of California Press, 2006.

London, Jack. "A Royal Sport" in The Cruise of the Snark: Jack London's South Sea Adventure. Santa Barbara: Narrative Press, 2001.

Marchand, Roland. "Apostles of Modernity." Advertising the American Dream. Berke ley: University of California Press, 1985.

"Matson Line." Advertisement. Forum (1886-1930). April 1, 1928. 69. ProQuest American Periodicals.

“New Hawaiian Constitution Adopted July 7, 1887." The Daily Bulletin. July 7, 1887. Chronicling America: Historic American Newspapers. Lib. of Congress.

Park, Gene. "Royal Hawaiian Closing for 7 Months." Honolulu Start Bulletin. June 1, 2008.

"Pinkham Plan to Reclaim Waikiki to be Tried." The Pacific Commercial Advertiser. March 16, 1906. Chronicling America: Historic American Newspapers. Lib. of Congress.

"Pinkham Plans the Reclamation of All Waikiki." Evening Bulletin. February 21, 1906. Chronicling America: Historic American Newspapers. Lib. of Congress.

“Royal Hawaiian Hotel.” Advertisement. Vogue. October 1, 1927.

Said, Edward W. Orientalism. New York: Vintage Books, 1979.

"Sluiced Lagoon Water into Waikiki Water and Drove Fair Bathers Away." The Pacific Commercial Advertiser. February 16, 1913. Chronicling America: Historic American Newspapers. Lib. of Congress.

“The Bank of Hawaii.” Advertisement. Los Angeles Times. January 1, 1925. 
“Truth About Waikiki Beach.” Los Angeles Times. June 6, 1920. ProQuest Historical Newspapers.

Whitehead, John S. "Western Progressives, Old South Planters, or Colonial Oppressors: The Enigma of Hawaii's “Big Five” 1898-1940.” Western Historical Quarterly 30. Oxford University Press, 1999.

Wiegel, Robert L. "Waikiki Beach, Oahu, Hawaii: History of Its Transformation From a Natural to an Urban Shore.” Shore and Beach 76 (Spring 2008), 3. 